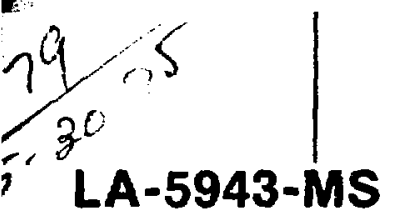

Informal Report

\section{One-Dimensional Calculations of Shock-Loaded Polycrystalline Beryllium}

by
Richard E. Swanson

by
Richard E. Swanson
UC-32

Reporting Date: Aprif 1975

Issued: April 1975

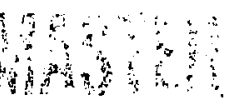


In the interest of prompt distribution, this report was not edited by the Technical Information staff.

Printed in the Uniled State of America. Available from National Tochnical Information Service

US Dopartment of Commerce

5285 Port Royal Road

Springtiold, VA 22151

Price: Prinled Copy \$.00 Mictoticho \$2.25

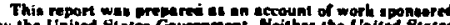

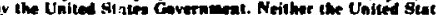

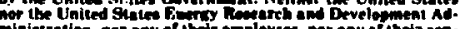

miniatration. nor any of their toptayeses, wer any of their con.

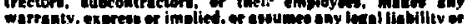

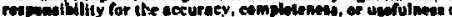

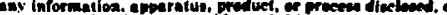

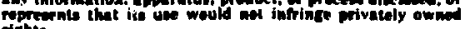


This repot Not

Shis report was prepared as an account of work

sponsored by the United States Government the United States nor the United States Energy Research and Development Administration, mor any of their employees, nor any of their contractors, warranty, express or their employes, maks liability or an legal or usefulnes of any if process uct or infringe privately owned rights.

ONE-DIMENSIONAL CALCULATIONS OF SHOCK-LOADED POLYCRYSTALLINE BERYLLIUM

by

Rtchard E. Swanson

\section{ABSTRACT}

Th1s report describes a numerical study of the response of polycrystalline beryllium to shock loading. We dtscuss various methods of Incorporating materlal properties relations to Improve the hydrodynamic calculations and propose a treatment whereby the anisotropic, polycrystalline nature of beryl11um can be modeled. We present the results of calculations, compare them with experimental date of several investigators, and coment on the applicabillty of the treatment.

\section{INTRODUCTION}

Calculation of polycrystalline beryllium response to plate impact experiments has not been successful using the normal technique of hydrodynamic calculations incorporated with an elastic perfectly plastic (EPP) treatment. Calculations of the freesurface velocicy profiles of three experiments (Nos. 1-3) Indicate that, without assuming a phase change upon shocking, the observed veloctry of the rarefaction wave cannot be reproduced. The observed ramped elastic precursor is also not calcliated by this method. The results of calculations using the EPP model with a yield strength $\left(Y_{0}\right)$ of $0.15 \mathrm{GPa}$ (1.5 kbar) are compared with the experimental profiles of Taylor ${ }^{\star}$ (Expt. Nos. 1 and 2) in Fig. 1.

The experiments shown in Fig. 1 were performed using the same material, target thickness, and driver plate velocity but with different driver plate thicknesses. Therefor', the observed difference between the two expertments in the rise of the profile is not exriainable. Christman and Feistmann ${ }^{1}$ also noticed such an effect, which was concludes to be real and due to a material effect that would include materfal properties. No proposed theorfical

\footnotetext{
*J. W. Taylor, Log Alamos Sctentific Laboratory, un-
} published data (1967). treatment will produce this difference if Identical samples are assumed.

II. DISCUSSION

Certain mechanisms for treating the behavith of polycrystalline beryllium can be considered. One is

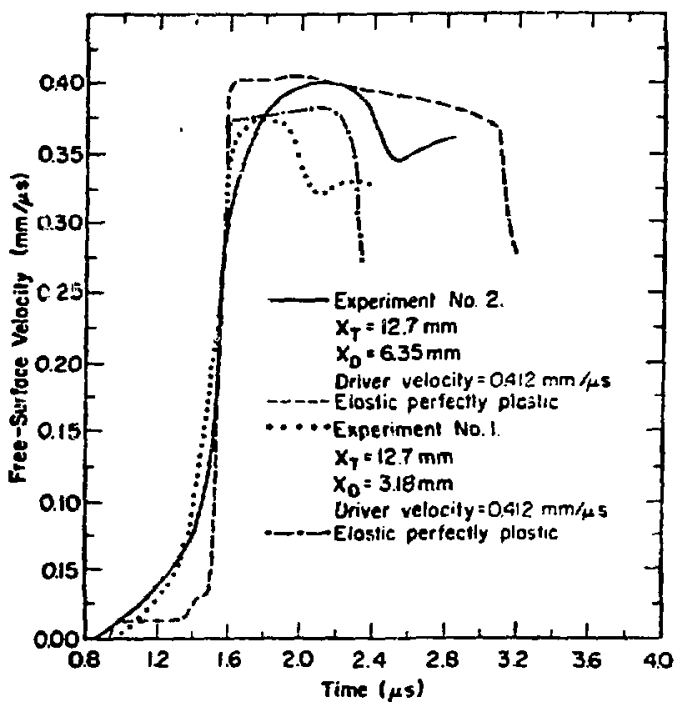

FIg. 1. Experimental and calculated free-surface velocity profiles for polycrystalline plate impact experiments. 
the existence of a phase transition upon shock loadIng which changes the bulk propertics of the material. Th1s possibility would not explain the observed ramped profiles and does not seer likely.

Another possubility to to treat the strain hardening properties of the bexyllium. IncorporatIng the strain hardening properties and the BaugchInger effect alters the character and magnitude of the elastic precursor and raxefaction waves and thus shows promise in explafining the observed profiles. We used the strain hardening and Baugchinger effect relations proposed by Read. 2

$Y=\left\{\begin{array}{l}\mathrm{T}_{0} \sqrt{1+\mathrm{c}_{0} \varepsilon_{p}} \quad \text { Inttial loading } \\ Y_{\infty}\left[1-\exp \left(-c_{1} \sqrt{\varepsilon_{p}^{\text {max }}-\varepsilon_{p}}\right)\right] \begin{array}{l}\text { reverse } \\ \text { loading }\end{array}\end{array}\right.$

$Y=y i e l d$ strength,

$y_{0} \quad=$ inftial yleld strength,

$\mathbf{y}_{\infty} \quad=$ asymptotic value on reverse loading,

$c_{0}, c_{1}=$ coefficients selected to fit quasi-static data,

$\epsilon_{p} \quad-$ equivalent plastic strain, and $\varepsilon_{p}^{\max }=\begin{aligned} & \text { maximum plastic strain attained during } \\ & \text { Initial loading. }\end{aligned}$

Where

$Y_{0}=0.135 \mathrm{GPa}$,

$Y_{\infty}=0,220$ kbar,

$c_{0}=74$, and

$c_{1}=17$.

The incorporation of these relations produced the velocity profiles shown in Fig. 2. We used the SIN code described in Ref, 3 to perform calculations In this report. The technique for Incorporating strain hardening models in the SIN code is given in Ref. 4. Obviously, the strain hardening prescription as presented (that $1 \mathrm{~s}$, as determined from quasi-static experiments) does not refroduce the data. However, the prescription could be refined by assumIng different hardening behavior at high strain rates to nacch the observed proftles. For example,

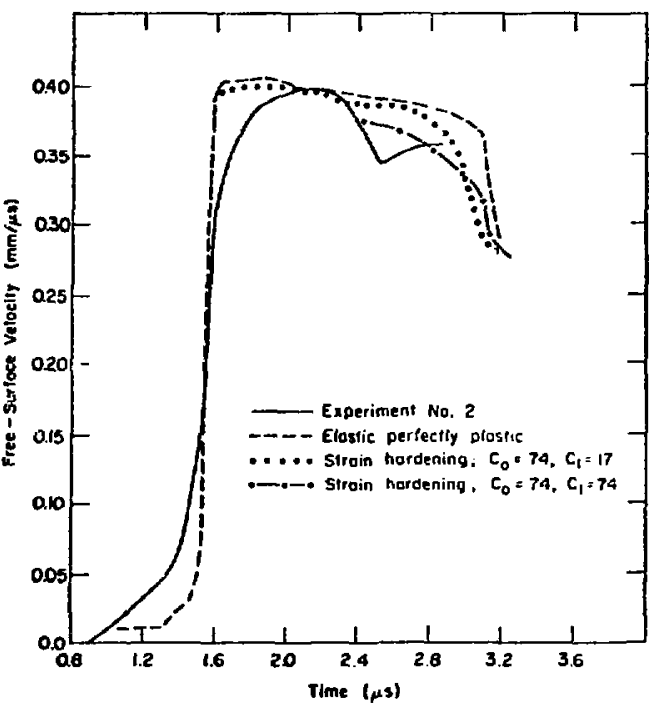

F18. 2. Experimental and calcusated free-surface velocities of a 12.7-mm beryllium plate Jriven by a 6.35 -mom berylilum plate initlally traveling at $0.412 \mathrm{~mm} / \mathrm{ps}$.

to produce the calculated profile shown as the dashdot line in F1g. 2, we increased the value of $C_{1}$ to simulate increased hardening or reverse loading. Certainly strain hardening propertles should be considered in a complete treatment. We think that the polycrystalline nature of beryllium should also be a primary consideration.

Pope and Johnson 5 and Pope and Stevens ${ }^{6}$ reported on wave propagation in single-crystal beryllium. They studied the free-surface velocity profiles of the single crystals which were subjected to planar shuck load $f_{1, b}$ along varfous directions with respect to the crystal planes. Their data showed that the elastic precursor was well defined and not ramped as observed in polycrystalline beryllim experiments. They made the interesting conclusion that the response of the polycrystalline beryllium is a consequence of the grains in aggregate rather than a consequence of some intrinsic property of the beryllium. Stiavens and Pope ${ }^{7}$ performed experiments on hot pressed polycrystalline beryllium after the texture of the samples was varled by rolling. The effect of rolling was to increase the concentration of basal planes nominally parallel to the rolling direction (normal to the shock propagation direction). They describe the texturing of the as-pressed material as 
having randoin $R$ intensity and measured the texture In three rolled samples as having intensities of $3 R, 5 R$, and $8 R$ relative to the as-pressed mater $1 a l$. The wave profiles observed in these experiments are shown in F1g. 3a along with an elastc perfectly plastic calculation of the responee. They also measured sound speeds in the samples and concluded that, as texturing Increased, the number of C-axes parallel to the wave propagation direction increased and therefore the speed was wetghted toward tint higher value of sound speed nbserved in the direction of the c-axis in single crystal samplee. This resulted In a higher ( $13.79 \mathrm{mml} / \mathrm{ss})$ sound speed measured in the highly textured (BR) material as compared to the sound speed (13.44 mm/ $/ \mathrm{s})$ measured in the $1 R$ material. This phenomenon is a result of the orientation of the grains in the polycrystaline material. Stevens and Pope proposed a model for unrelaxed thermal microstresses to explain the observed ramping (supressing of the elastic precursor) In the as-pressed matertal.

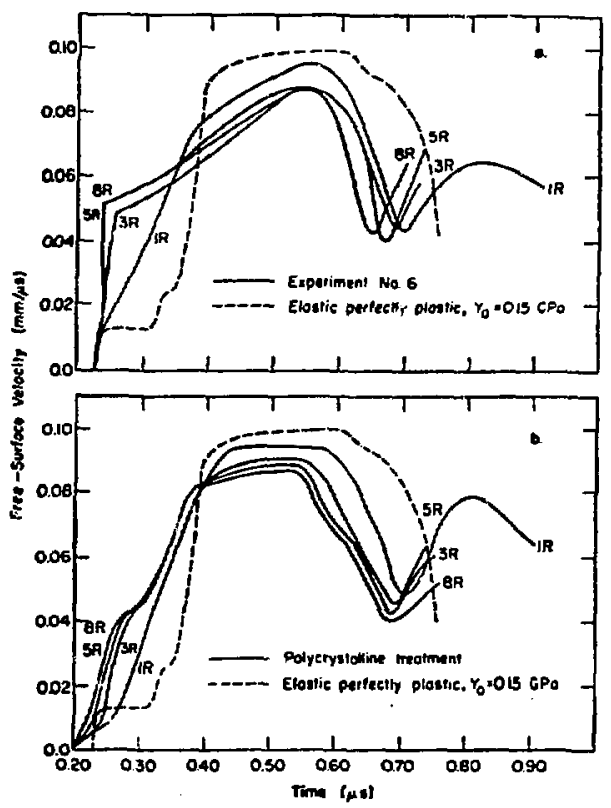

F1g. 3. a. Experimental and calculated free-surface velocittes of a $3.00-\mathrm{mm}$ beryllium plate driven by a $1.00-\mathrm{mm}$ fuzed quartz plate Inttally traveling at $0.120 \mathrm{~mm} / \mathrm{\mu s}$ where the texturing of the beryllium was varted.

b. Calculated profiles of the same experiment using the polycrystalline treatment.
III. CALCULATIONAL MODEL

Facts wuch as those discussed above lead to the conclusion that a proper method for calculating the response of beryllium should treat the anisotropic, polycrystalline nature of the material in hydrodynamic computer codes. We considered individual beryllium cells in the calculation as representing grains oriented in aeparate directions and assigned the cells different yleld values since the :'enomenon of different yield strengths along different crystal directions is observed. ${ }^{5, B}$ We call the method described below the polycrystalline treatment.

In the crudest sense, consider a slab of beryllium with two types of grain orfentations distributed randomly with respect to the planar shock propagation direction. One group of cells (the even ones) is orlented such that the yleld strength is amall $\left(\mathrm{Y}_{0}=0.075 \mathrm{GPa}\right)$ and the other group (the odd ce1ls) Is orlented such that the yield strength is $0.4 \mathrm{GPa}$. For this case, the code treats the even and odd cells as shown in the Pressure-Specific Volume dragram of Fig. 4a. The response of the
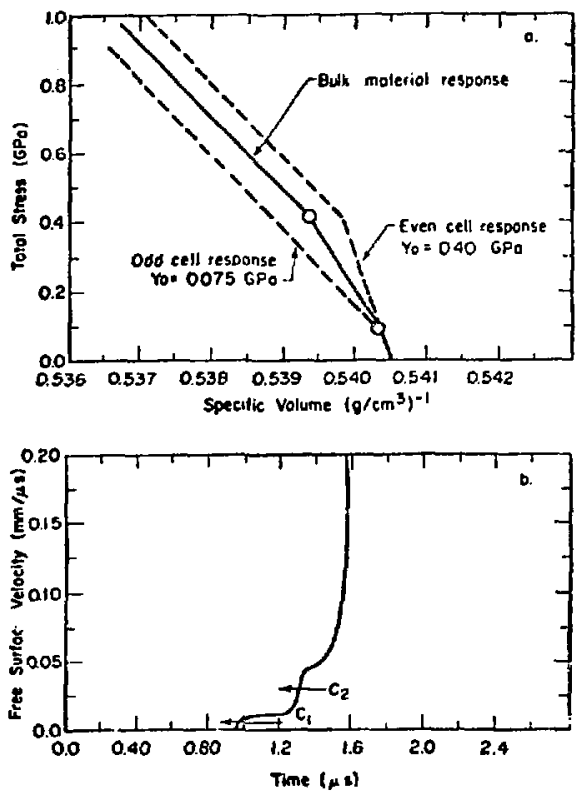

F1g. 4. Representation of the response of a material assumed to have two different ylold strengths evenly distributed among the celle. 
che aggregate aaterial is represented by the average response show by the solid IIne. If the ratio of higher yield values to lower yteld values was changed, the average response would be welghted accordingly. Likewise, if more than two different y teld were usalgned, the responoe of the aggregate aacertal would be represenced by more than one change of slope of the sol 1d line. The goldd line Kugoniat In the figure predicts two vaves traveling at congtant velockties $\left(c_{1}\right.$ and $\left.c_{2}\right)$ represented by the slopes of the line segwents. Then two "eluotic" precursors with veloctites $C_{1}$ and $C_{2}$ and stress $\mathrm{mig}-$ nitudes given by $a_{1}-\frac{v}{1-2 v} Y_{1}$ and $a_{2}-\frac{v}{1-2 v} \gamma_{2}$ (v 1s Polsson's ratlo) are propagaced at shown in

Fig. 4b. Similar behavior 18 also exhibited by the elast 1c components of the rarefaction, the firat rarefaction wave travels at velocity $C_{1}$ and the second at velocity $C_{2}$. Figure 5 shows the calculated pressure profiles in the material as the wave propagates.

Figure 6 shows how the code treats such a altuat1on. Plotted are the total stress, particle
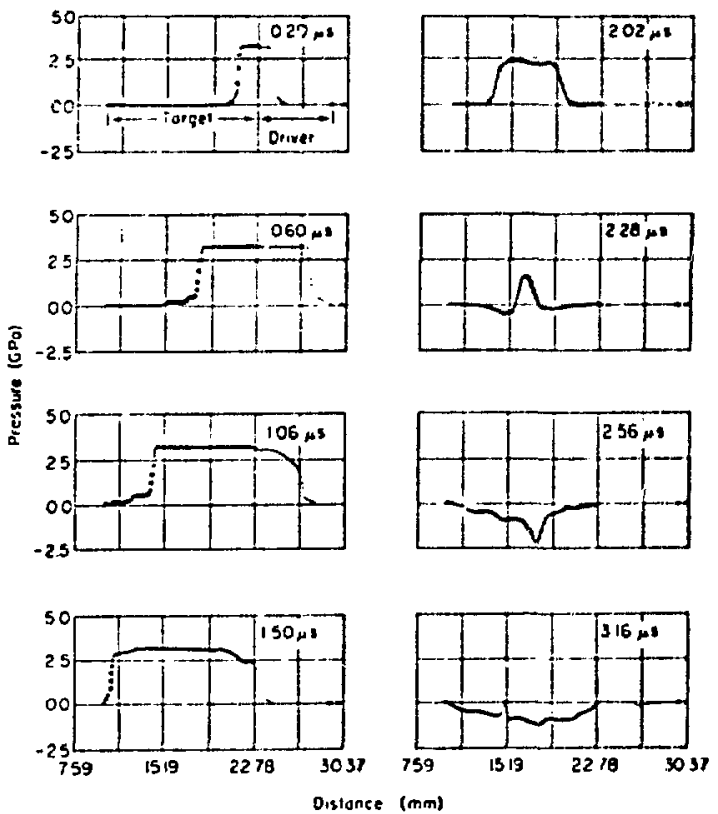

F1g. 5. Computed pressure-distance profiles for experiment No. 2. The driver plate 18 shown as a light line, and the earget plate as a heavy ilne.

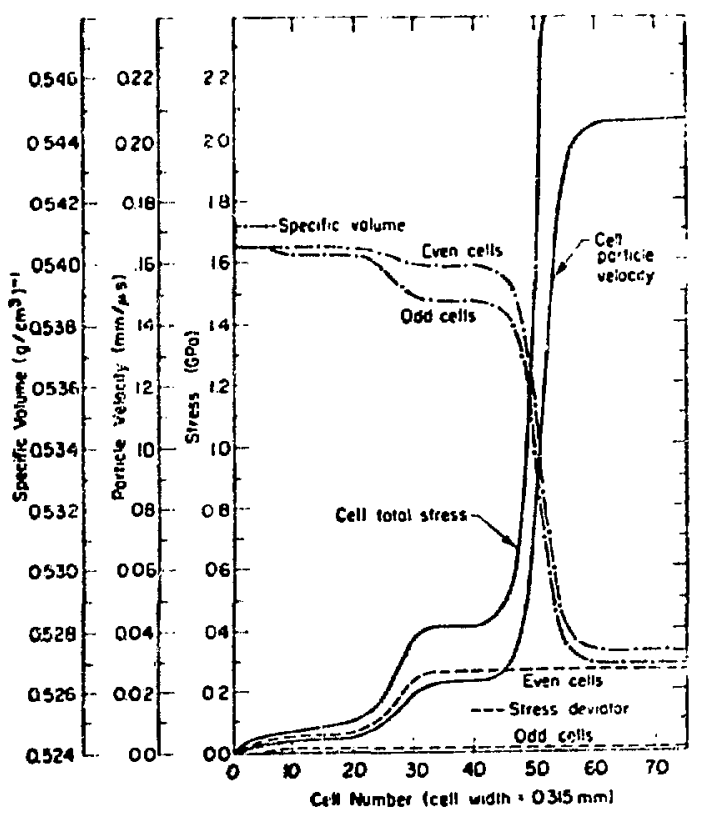

FiB. 6. Total stress, particle velocity, atress devlatur, and spectiftc volume proflle as calculated using the polycrystalline r reatment.

velocity, stress deviator, and spectfle volume proflles in the beryllium as the compressive waves prupagate. Note that the pressure and partlcle velocity are continunus since they are matched frow cell to cell. The discontinuous nature of the yteld strength is compensated for by the discontinulty in the compression. This metion has proven to be Independent of wesh stze.

By varying the distribution of cells and thelt yleld strength, a large varlety of proflles can be produced. Increasing the number of one yleld atrength over another has the effect of "textur Ing" the sample. Figure 7 shows typical calculations performed during a parameter study where the magnicudes and wave speeds of the elastc components of the waves vary as the y1fids and distribution of the ce!ls are varied.

For convenience we use the following notation to Indicate the yield strength values used for the polycrystalline model.

$$
Y_{0}=\left\{Y_{1}, Y_{2}, \ldots, Y_{n}\right\} \mathrm{GPA} \text {, neaning }
$$




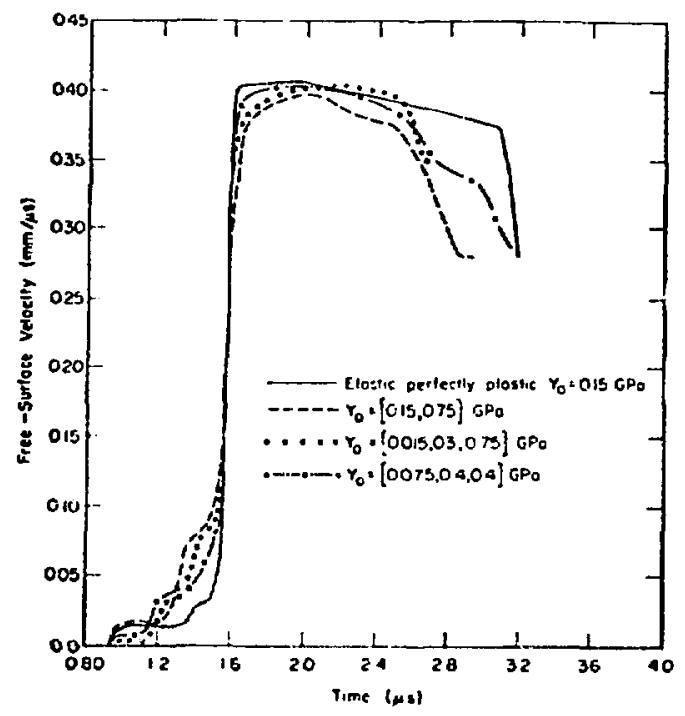

FiB. 7. Calculated free-surface velocities of a 12.7-m beryllium plate driven by a 6.35 meryllium place intelally traveling at $0.412 \mathrm{~mm} / \mathrm{us}$.

$Y_{0}=Y_{1} G P a$ every first cell of a block of $n$ cells $Y_{0}=Y_{2} \mathrm{GPa}$ every second cell

$\cdot$

$\dot{\gamma}_{0}=Y_{n}$ GPa every $n^{t h}<.11$.

For example, in Fig. 7, the notation $Y_{0}=10.75$, $0.15]$ GPa Indicates that all the odd numbered cells were assigned a value of $Y_{0}=0.75 \mathrm{GPa}$ and $t$ he even numbered cells were assigned a value of $Y_{0}=0.15$ cPa.

of course, In polycrystalline beryll lum the gratns are orfented in an ext remely complicated, chree-dimensional way and the Interactions between the individual grains are also complicated. We attempted to Indicate the effects of such randomess by averaging the effects of the crude polycrystalIne treatment using a real viscosity factor. Certainly, we could incorporate enough viscosity to suear out and obscure the effect of the trestment. Figure $B$ shows a parameter study of the ef fect of real viscostty on calculations of beryllium impact experiments. A viscosity factor of $2 \mathrm{kP}$ was found

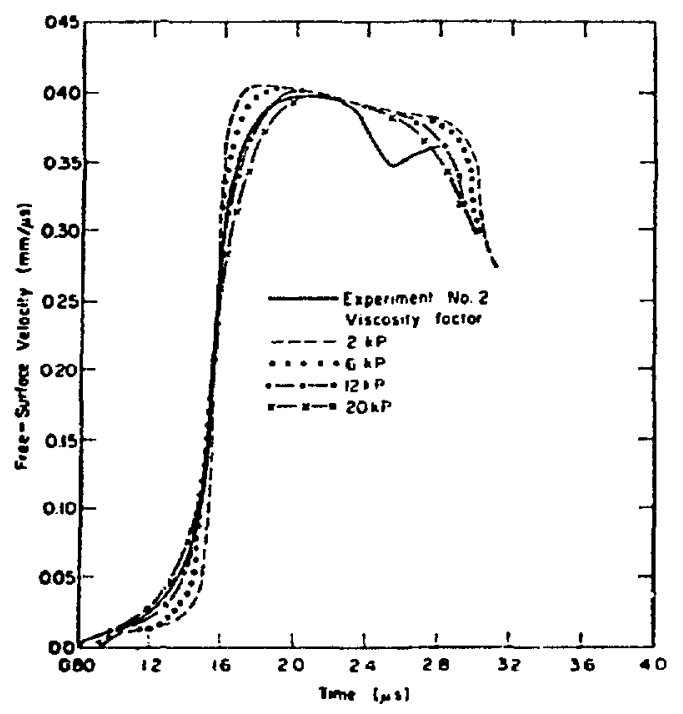

F1g. 8. Experimental and calculated free-surface velocities of a 12.7- $\mathrm{mm}$ beryllium place criven by a 6.35-kan beryllium plate iniilally traveling at $0.412 \mathrm{mof} / \mathrm{pl}$.

to reasonubly desct the the response of aluminum durIng plate Impact experiments for shock pressures of 2.0 to $10.0 \mathrm{CPa}^{4}$ Thus we do not cons1der a viscosity factor of $3 \mathrm{kP}$ an unreasonable value for beryllium. He used the one-dimensional hydrodynamic code $\mathrm{SIN}^{3}$ to perform the calculations. We treuted the spalling observed in Expt. No. 6 by using the pressure gradtent spall model ${ }^{3}$ with a Spall A constant of $8.5 \times 10^{-4}\left(\mathrm{GPa}_{\mathrm{am}}\right)^{1 / 2}=0.027(\mathrm{Mbax} \cdot \mathrm{em})^{1 / 2}$. The rssults of calculations are compared with experimentally detemined wave proftles in section $v$.

The equation-of-state parameters used in the SIN code to describe the response of the materlals consldered are listed below. The nomenclature and unlts are Identical to thosc used in Ref. 3 and are described in detall there. We treated the fuzed quartz (FQ) at an elastic watertal for the stress ranges experienced by the quartz in the experiments stud1ed.

\begin{tabular}{lll} 
& \multicolumn{1}{c}{ Bery111um } \\
$C$ & 7.975 & -01 \\
$S$ & 1.091 & +00 \\
$F_{S}$ & 2.07189823068 & +00 \\
$G_{S}$ & -2.90125259335 & +01 \\
$H_{S}$ & -7.55281579097 & +01
\end{tabular}




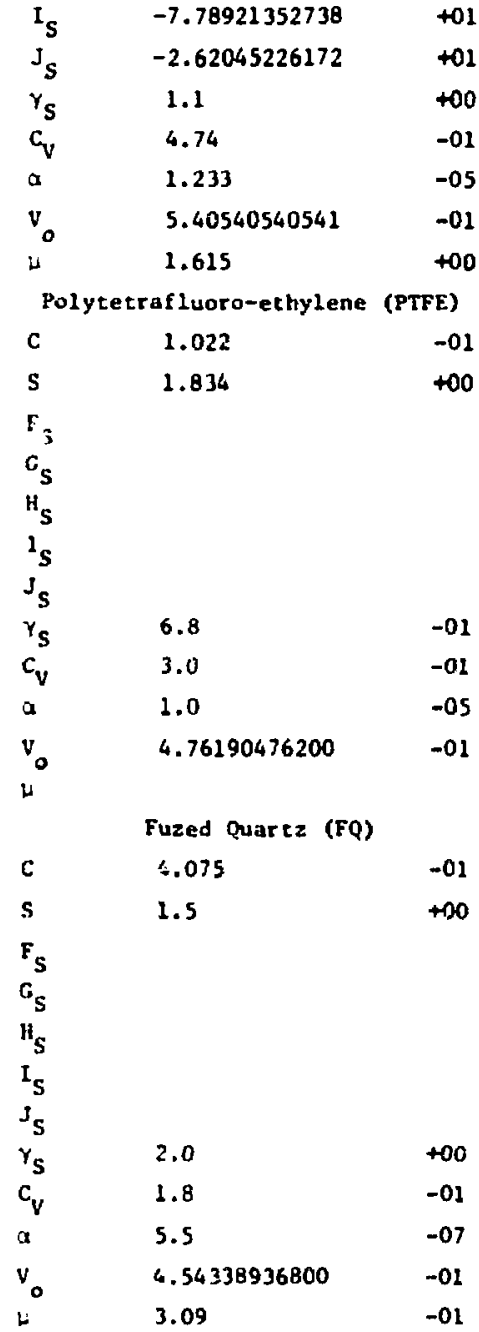

IV. EXPERIMENTAL DATA

A sumary of the experiments studied in this report 10 given in Table I. Experiments 1 and 2 were performed by J.W. Taylor who Impacted carget plates of polycrystalline beryll fum with beryllium drtuer plates and monttored the cime-tesolued freesurface velocity of the rear surface using the d-c capacicor technique.

Experiment No, 3 was performed by $P$. Fuller of the Atonlc Weapons Research Fistablishment,

\footnotetext{
ॠ. W. Taylor, Log Alamos Scientific Laboratory, unpublished data (1967).
}

TABLE I

SUMMARY OF EXPER MAENTS

\begin{tabular}{|c|c|c|c|c|c|c|}
\hline \multirow{2}{*}{$\begin{array}{c}\text { Expt. } \\
\text { No. } \\
1\end{array}$} & \multirow{2}{*}{$\begin{array}{c}\begin{array}{c}\text { Dr lver } \\
\text { velocity } \\
(\mathrm{wm} / \mathrm{Hg})\end{array} \\
0.412\end{array}$} & \multicolumn{2}{|c|}{$\begin{array}{c}\text { Driver } \\
\text { (미) }\end{array}$} & \multicolumn{2}{|c|}{$\begin{array}{c}\text { Target } \\
\text { (aim) }\end{array}$} & $\begin{array}{l}\text { Target } \\
\text { Backing }\end{array}$ \\
\hline & & 3.18 & Be & 12.7 & Be & Free aurface \\
\hline 2 & 0.412 & 6.35 & Be & 12.7 & Be & Free surface \\
\hline 3 & 1.25 & 6.3 & Be & 12.7 & $B e^{a}$ & \\
\hline 4 & 0.351 & 1.509 & $\mathbf{F Q}$ & 6.203 & Be & $\mathbf{P Q}$ \\
\hline 5 & 0.346 & 1.524 & $\mathbf{F Q}$ & 9.149 & Be & $\mathbf{F Q}$ \\
\hline 6 & 0.120 & 1.00 & 80 & 3.00 & Be & Free surface \\
\hline
\end{tabular}

Manganin gauge lmbedded in PTFE 12.7 from Impact plane.

Aldermaton, England. the monltored the pressure in a polycrystalithe I 400 beryllium target with a pressure gauge imbedded $12.7 \mathrm{mog}$ from the fmpace surface. Chriseman and Feistmann cested S-200F. Type I, hot prested block Brush beryllium extenstvely. Experiments Nos. 4 and 5 are the reaule of two of thedr plate impact experiments. They monitored the particle velocity at the beryllium-quartz window interface using the interfurometric quartz window cachndque. The shock propagestion direction was patallel to the fressting direction. They noted litele evidence of structura or texituring in the mapples. However, chey did observe some clastic antsotropy which inplies a cryatalloxraphic anisokropy.

Experiment to. 6 la actuslly a serles of several shote performed by stevens and Pope ${ }^{7}$ where the texturing of the beryllium wos varled to diecused in Secetion It. They used Kaweck1-Berylco hot pressed HP-10 beryllium and annealed the samples prior to cexcuring. Ito laser toterferometric cechnique was used to mositor tite free-giurface veloctey during the plate impact experisents.

The lack of knowledgo of the texturing and prior treatment of the berylltim used for mose of the experimente sfudied maken is difficult to relate the results of different tesi serles to each other.

v. RESURTS

The comparisor, of experimental and calculated resules is shown in Fif;. 3 and Figs. 9-13. We

Unpublished daca. 
qualitatively simulated the effect of texturing of the beryllfum by changing the rat 10 of yleld strengths, thus textur ing the material in the calculat lons as discussed in Section III. Figures $3 a$ and $3 b$ compare the results of calculation and experiment.

In F1g8. 9-11, the treatment 1s shown to better reproduce the ramped elastic precursor and velocity of the elastic component of the rarefaction. However, the agreement is still not sat1sfactory. For Expt. No. 3 (F1g. 11) the beryll1um expertences over $10.0 \mathrm{GPa}$ (100 kbar). Under these conditions, che occurrence of a phase change on shocking is a greater possibility.

Figures 12 and 13 illustrate the difficulty of deterwining parameters from one set of experiments and applyting them to experiments where beryllium with different treatment history and texturing is used. For these two experiments we were unable to mutch both the observed behavior of the elastic precursor and rarefaction waves without considering effects outside the sope of this report.

Vi. COACLUSION

Obvlousiy, more work must be done to properly characterize the response of polycrystalline beryj11um. This report demonstrates that the polycrystalline treatment can be used to reproduce certain aspects of the observed response. It should be considered when effects such as strain hardenting and rate dependence (e.g.. real viscosity) are studied.

\section{ACKHOLLELXMENTS}

The author gratefully acknowledges the cuntr1but lons of J. W. Taylor, J. F. Barnes, P. J. Belwett, and 6 . T. Rood of the Los Alamos Scientific Laboratory; J. M. Walch of Systems, Science and Software:
A. L. Stevens and L. W. Davison of Sandia Laboratories; and espectally the encouragement and assistance of $C . L$. Mader of the Los Alamos Selentific Laboratory.

Spectal acknowledgment goes to the Laboratory Assoclate Program of the USAF A1r Force Systems Command which made the completion of this atudy possible.

This work was performed in the Theoretical D1vislon of the Los Alamos Sclentific Laboratory.

\section{REFERENCES}

1. D. R. Chr1stman and F. J, Felstmann, "Dynam1c Propert les of S-200-E Beryllium," Materlals and Structures Laboratory, General Motors Corporation report MSL-71-23, DNA-2785F (1972).

2. H. E. Read and R. A. Cec11, "A Rate-Dependent Const1tut Ive Model of Shock-Loaded S-200 Bery1lium," Systems, Sclence and Software report DNA-2845F (1972).

3. C. L. Mader and W. R. Gage. "FORTRAN SIN A OneDimensional Hydrodynamic Code for Problems Which Include Chemical Reactions, Elastic-Plasi1c Flow, Spalling, and Phase Transitions," Los Alamos Sctentific Laboratory report LA-3720 (1967).

4. R. E. Swanson and C. L. Mader, "One-Dimenstonal Elastte-Plastic Calculations Involving Strain Hardening and Strain Rate Ef fects for Aluminum," Los Alamos Scientific Laboratory report LA-5831 (subultted for editing).

5. L. E. Pope and J. N. Johnson, "Shock-Wave Cumpression of Single-Crystal Beryllium," Sandla Laboratories report (submitted to J. Appl. Phys.).

6. L. E. Pope and A. L. Stevens, "Wave Propagation in Berylilum Single Crystals," Sand 1a Laboratories report SC-LA-101.

7. A. L. Stevens and L. E. Pope, "Wave Propagation and Spallation in Textured Beryll lum," Proc. of Conf. on Metallurglcal Effects at $\mathrm{H} 1 \mathrm{gh}$ Strain Rates (Albuquerque, M, February 5-8, 1973).

8. J. W. Taylor, "Stress Wave Profiles in Several Metals," In D1slocation Dynamics, A. R. Rosenfleld, G. T. Hahn, A. L. Bement, Jr., and R. I. Saffe, Eds. (McGraw-H111, New York, 1968). 


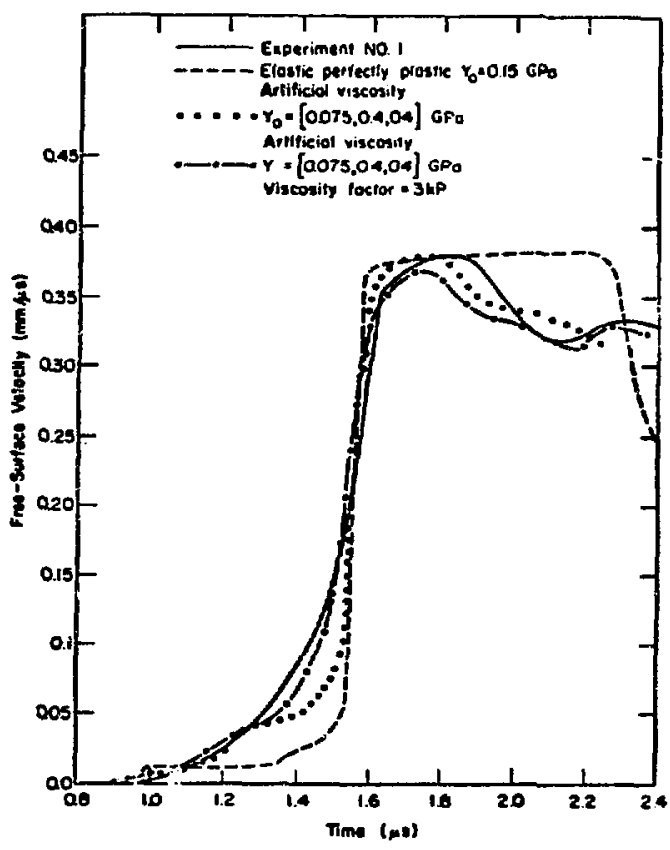

F1g. 9. Experimental and calculated free-surface velocities of a $12.7-\mathrm{mm}$ berylitum plate driven by a 3.18-min beryll lum plate Initlally traveling at $0.412 \mathrm{~mm} / \mu \mathrm{s}$.

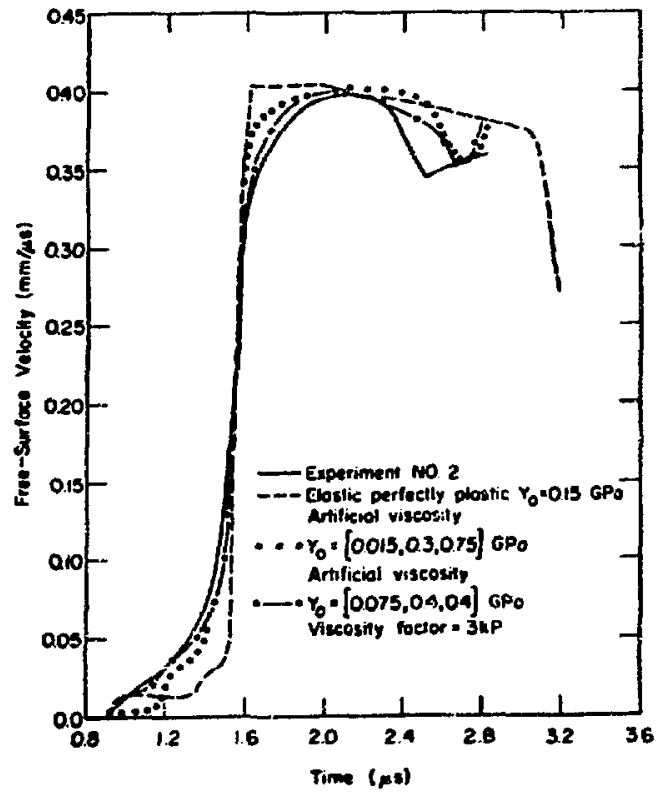

F1g. 10. Experimentai and calculated free-gurface veloclties of a 12,7-m beryllius plats driven by a 6.35-am berylliam piote intthally traveling at $0.412 \mathrm{~m} / \mathrm{ms}$.

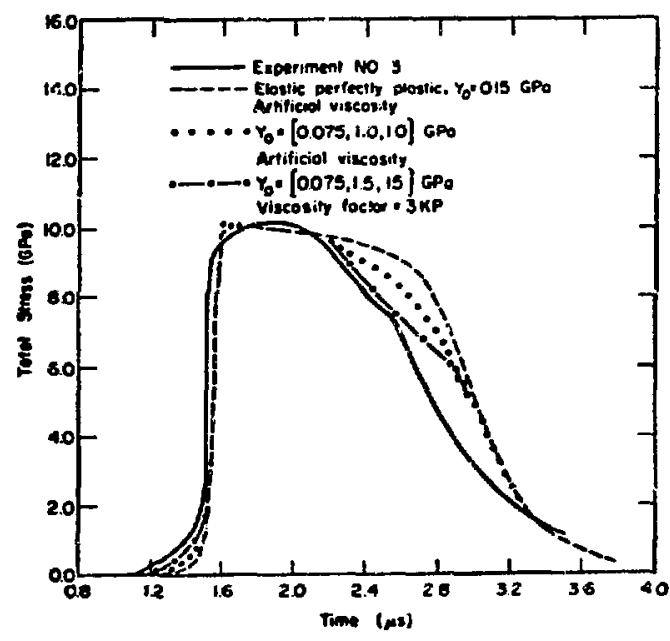

F1g. 11. Experimental and calculated otress profiles of a 38-moln beryllium plate $(0.25-\mathrm{mm}$ PTFE with an 1mbedded manganin gauge 12.7 nim the impact surface) driven by a 6.3-m beryll lum plate infelally traveling at $1.25 \mathrm{~mm} / \mathrm{\mu r}$. 


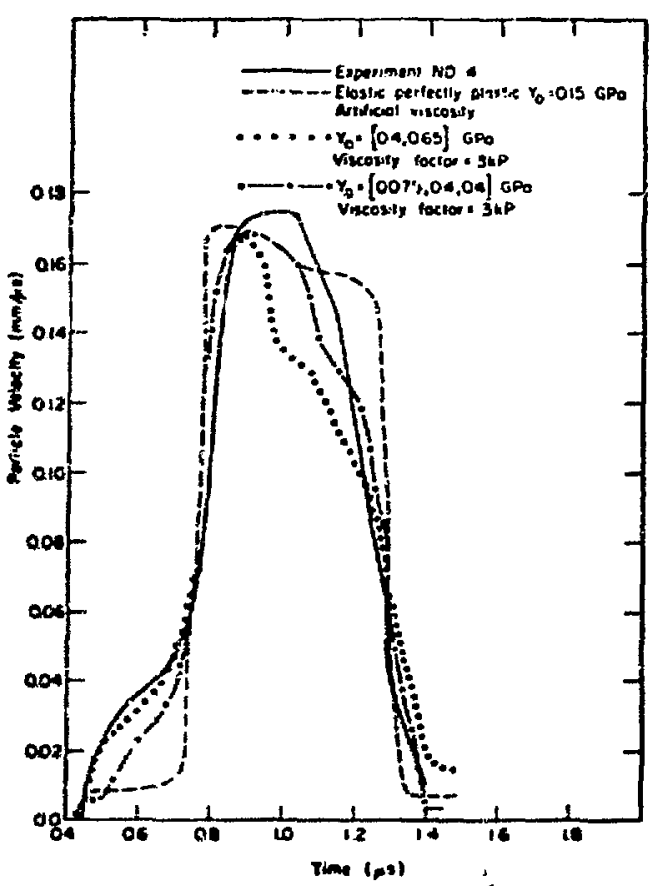

1

118. 12. Expertuental and calculaced oretcle velnctiy at the beryillum-quariz window interface of a 6.203-ma beryllium plate drtuen by $a 1,509-f u z e d$ quarte plate intthally craveling at $0.351 \mathrm{mo} / \mathrm{fras}$.

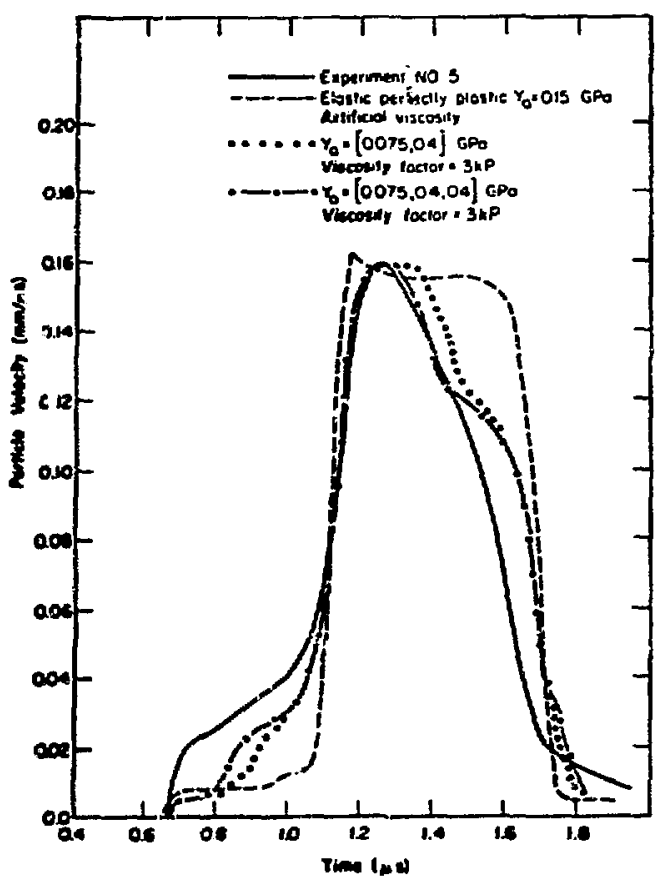

F18. 23. Expertmental and calculated particle velactly at the beryll lum quartz whidow interface of a 9.149-rom beryllium plate driver by a 1.524 -m fuced quart 2 plate Initially traveling at $0.346 \mathrm{~mm} / \mathrm{hs}$. 